\title{
Psychodynamics of Mother Daughter Relationship: Degrees of Deprivation, Oppression and Dispossession in Doris Lessing's Fiction
}

\author{
Rabia Ashraf \\ COMSATS Lahore, Pakistan
}

\section{Introduction}

The aim of this study is to explore how Doris Lessing's works disclosein prominence the power dynamics of the conflicted and struggling relationship of mother and daughter, the paradigm of mother daughter relationship and its psychodynamics including explanations about the developmental stages of the relationship between the mother and the daughter, human behavior of the two in the context of relationship formation and maintenance, psychopathology where the daughter feels isolated and the psychoanalytic dimensions of treatment of this particular relationship, primarily in the world of psychoanalytic and feminist literary history. Resultantly, it has been unfolded that the phenomenon of mother daughter relation holds immense complexity and layers of intricacies in the feminist discourses where the presence of a mother figure has been deconstructed both thematically and stylistically as evident in Greek plays. Mother daughter relation has always enjoyed being of significance, at times appearing titled as 'Electra Complex' after Sophocles' Electra while at others emerging out as the phenomenon of 'Matrophobia' as titled by Sukenick and carried on further by second wave of feminists (Hallstein 8).

Doris Lessing provides prominence to the mother daughter dynamics in much of her works particularly her self-representational fiction and purposely delineates a stance where daughter's relation with the mother is conventional and unconventional on the same plane. "The mother daughter relationship has been described as most ambiguous, ambivalent and challenging than any of the other three parent child dyads (mother-son, father-son, and father-daughter) (Shilpa 6). According to Boyd, "no matter how much feminist theory has attempted to define 
Rabia Ashraf

female sexuality outside Freud's sexist theories, one thing remains intact: the ambivalent nature of the mother daughter relationship" (Boyd 291).

Under My Skin and The Grass is Singinghold a place where feminist and psychoanalytical thought of daughter's psychic clash with the mother as evidently and symbolically embedded and merged within the texts. Highly subjective, self representational and autobiographical narrative mood of the texts highlight the element of self understanding on part of the author. AncaGeorgescu, in this regard states her opinion that life writing has enabled Lessing to deal with the difficulties of her life using a subjective method (3). Lynda Scott opines about Lessing's attempt of writing the truths and confessions of her life as more tilted towards being literary therapeutics. She critique's on Lessing's stance of choosing the mother daughter theme in the following words:

She [Lessing] is able to recreate past selves and commune in an inner dialogue with earlier and necessarily fictive selves while constructing a coherent text that represents a healed and unified self at a particular instant in time. Because an individual's perception of her or his self is forever changing and the unconscious realm is a dynamic one, the self-representational text is also a historical artifact, and may be likened to on-going records of therapy sessions. (Scott par 2)

Motherhood and mothering have been explored by feminists after the subject appeared to hold significant importance in the critical discourses and feminist fiction cum literatureparticularly at the end of the twentieth century (Hallstein 1). The empowering, all encompassing and oppressive dimensions of maternity as well as the complex relationship with the mother are depicted in Of Woman Bornwhich is credited to be one of the first feminist texts to explore motherhood and motheringand is widely acknowledged and credited by contemporary feminist scholars in this realm (Hallstein 1). In Europe and European texts, works by Adrienne Rich, Of Woman Born: Motherhood as Experience and Institution and Alice Walker's Essay "In Search of Our Mothers' Gardens" can be termed as turning points in understanding of mother figure particularly in European texts. Nancy Chodorow'sThe Reproduction of Mothering which also came up in 1970's deals extensively with the issue of gender polarities and the identity issues between the daughter and the mother especially those that affect the daughter. 


\section{Relational Similarities and Identity Formation of the Daughter}

Nancy Chodorow states about the role of a mother figure in a daughter's life in following words: "Women define and explain themselves relationally, especially in relation to mother issues" (207). The mother figure thus becomes the emanating source of the identity of the daughter to which she continually relates and has to link back all her life. It colors the very making of the individual no matter how much time elapses for the newly born from being removed at the umbilical cord and fending ways in the world. The urge to go back to the womb is experienced by an individual at any time of his life no matter what the gender of the child is. The mother acts as a source and the connection that continually attracts the created being towards itself. She is all defining and all encompassing. Chodorow is of the opinion that the definition of a daughter is actually taken consciously or unconsciously but directly from her mother (208). Here, the role of a father or siblings enjoy their respective domains, with complexities of a different nature but the gender to gender flow of identity and personality traits is experienced perpetually and unhindered between a mother and a daughter and much passes from the mother to the girl.

Research into the particular realm elucidates thatmother daughter relation does not enjoy uniformity in terms of the strength of the bond between the two and corroborating to thisis the notion that this bond is ever fluctuating and an ever changing as time elapses and biological and psychological growth significantly of the daughter takes place (Shilpa 2). Also, it cannot be stated that mother daughter dyad is tilted towards either of extreme sides. According to Shilpa, in both the lives of the mother and the daughter, the relationship observes a continuous transition. According to her, "each life stage for both mother and daughter represents new challenges and opportunities for new relational integrations"(Shilpa 2). In her fiction and autobiographical works, Lessing immaculately describes the ups and downs and complexities of her relation with her mother with bluntness of written discourse- of hatred or hate speech which is reminiscence of Lessing's personal life terms of identity crises with her biological mother. Hence, in her self-representational works starting it all from her birth to the time she has reached past being a mother, Lessing is clear, sharp, pithy and honest till root.

My mother chatted on and on...how all her talents were withering unused, how the little girl in particular (she was so difficult, so naughty!) made her life a total misery. And I was a 
cold flame of hatred for her. I could have killed her there and then. (Emphasis added, UMS 30)

These lines echo not only the mother being uncomfortable regarding Lessing but also a severe and extremist reaction from the daughter so much so that Lessing feels a desire to kill and get rid of her mother. There are moments, as depicted in her autobiographical works when her relation with her mother is at utter decline particularly after she leaves the home at the age of twenty six. Before this time, the mother's constant influence on her identity formation affects negatively. So, after her death, Lessing defines her subjectivity in relation to her mother at various moments of her life, aiming simultaneously to untangle her diffused identity with that of her mother and understanding her difficult relationship with her mother and also making an attempt of embracing or relating to it. This is also true to Mary Turner in The Grass Is Singing who is unable to get rid of the memory of the struggling life of her mother when she was young. Mary envisages her life with Dick Turner in relation to her mother's life with her husband in Southern Rhodesia (GIS 1950). Therefore, she manages to bring out the relational similarities between herself and her mother as two such objects that have to make the ends meet by remaining within the resources both mentally and financially. Therefore, at various stages of her life the dynamics of daughter's way of viewing and opinionating the mother fluctuate.

The adult woman who is mother, in particular, continues to existonlyin relation to her child, never as a subject in her own right. And, in hermaternal function, she remains an object, always distanced, alwaysidealized or denigrated, always mystified, always represented throughthe small child's point of view. (Hirsh 167)

As Hirsch points out, the mother does not enjoy an identity of her own and is but a creation of the imagination and experience of the daughter. Her existence is in relation to the daughter who has full freedom of viewing her in her own particular way. The mother's treatment of the daughter and practicing her motherhood enables the daughter to either idealize the mother or possess an enigmatic view of her. Lessing's fiction presents the daughter's point of view in bildungsroman fashion. Through stages of development, the daughter gets her definition through her mother and in return defines her mother on the basis of the quality of her motherhood and womanhood. Lessing's subject matter is the figure of the mother but the dynamic, mobile and ever living is the presence of the daughter. 


\section{Matrophobia and Fissured Self}

As confirmed by now, matrophobia has connotations of hatred and causes splitting of the Self of mother and daughters from each other (Rich 1). Identity formation is crucial in early stages of the development of a child and the early stage of a child's life is the Mirror Stage as Lacan puts it. In this stage, the mother becomes the reflection of the baby daughter and she sees herself reflected in the mother and forms her mental representation of 'I' or the Self. This image that reflects back becomes ideal for the child which she aspires and strives for all her life. The mirror stage operates both ways for the daughter and the mother in Under My Skin. If Lessing sees in her mother the creator and savior of her existence then the mother sees an extension of her existence in her daughter. The level of expectation between both of these women achieves its zenith during the Mirror Stage. The daughter views a god mother in the face of her mother whereas the mother seeks imperfection in the woman that is born out of her. The distorted sense of self inherited by Lessing from her mother goes with her a long way till she is of age. The mother's practice of motherhood filled with imperfection leaves deep impressions on the daughter. Rich is of the view that for a drowning daughter, mother is the source of all those clues that explain to her what it takes and makes to be a mother (243). Lessing foreshadows getting almost no clues on mothering from her mother. As a teenager, she most hates in her mother "her pressure, her insistence, her close jealous supervision, her curiosity - all the pathetic identification of woman whose gratification is only in her children' (UMS 112). This fissured conception of mothering and motherhood leaves severe impressions upon her. The vulnerable relationship between Lessing (daughter) and Emily (mother) has a lifetime impact for both on both the women. As a teenager, Lessing's emotional turmoil of her sexuality and her mother's manipulation of her feelings as an oppressor stress out her sense of Self. Recalling her "erotic longings" as a teenager, she says that "it is [her]belief that some girls ought to be put to bed, at the age of fourteen, with a man even as much as ten years older than they are, with the understanding that this apprentice love will end" ( UMS 185). She argues that if she had been provided with such an "apprentice love" she would not have spent her adolescent years in this state of longing which she says "is a kind of homesickness, perhaps for past and not future Edens. It is an illness, incapacitating" (UMS 186).

The mother- Emily appears to suffer from a conflict between her self-preservation and the maternal feelings nature has embedded within her (Georgescu 2). For her 
mother, Lessing is "a little girl... [who] made her life a total misery" (UMS 30). With the birth of a daughter, Emily finds no solace or happiness but feels her sense of maternal self to be challenged. Lessing states her birth as a hard experience for her mother, "My mother had a bad time. It was a forceps birth" (UMS 8). Interestingly, a similar conflicted mother figure haunts Lessing's selfrepresentational writings like The Grass is Singing and Martha Quest. The conflict faced by Mary, Martha and Lessing is the conflict of generations that moves from generation to generation and is a gulf between the daughter and the mother that is never satisfactorily breached (Schlueter 46). Lessing suffers from the same matrophobia which her fictional character Mary and Martha suffer from and this is revealed through psychoanalytic study of the narrative discourse of both The Grass is Singing and Under My Skin (Gerorgescu 1-6). More explicitly, Martha and Mary suffer from matrophobia because Lessing felt it in her life and she consciously inculcates it while coalescence of life and literature takes place. Lessing re tells the tale of herself and her mother which is a story that "has indeed been written, although it is not found on the surface but submerged in depths of literary texts" (Hirsh \& Evelyn 204) in which language becomes that medium that expresses past by re capturing it and allows the reader to analyze the psychosis and neurosis of the author's persona embedded within it.

\section{Daughter's Fear of Becoming into/like Her Mother}

Like history repeating itself, the affected daughter runs from shaping into her own mother anytime in future. Second wave of feminists have dwelled extensively upon such a situation (Hallstein 8) and as already discussed, the mother figure has an authority over the daughter and is the source of daughter's identity formation, Sukenich, who used the term matrophobia in her work on Lessing providing a different perspective of it by relating that matrophobia is "the fear not of one's mother or of motherhood but of becoming one's mother" (Hallstein 8). Lessing does accept the fact all her life that she has been colored the way her mother was. She projects herself as a believer in determinism where the inherited traits are determined naturally and nurture has but little role to play. The fear is also that of identification with the one that one does not want to be identified with but has no control or authority over it. It is in such a situation that the daughter realizes that she lacks a concrete conception of pure womanhood or motherhood and her archetype of a mother is distorted. In Jungian conception of the "Mother Archetype", the mother is associated with "maternal solicitude', "sympathy", "magic authority", "wisdom", "spiritual exaltation" and all that is "benign, all that 
cherishes and sustains, that fosters growth and fertility" (Jung 139-140). Lessing and Martha are unable to relate to the positive archetype of their mother however, the other side of the Jungian Archetype, where the mother figure symbolizes darkness, mystery, anything that is terrifying and escapable" is well related in the context of their mothers. The life, its memory and the fate of the daughters based on the one of mothers is terrifyingly inescapable for the daughters. The daughter then has to live her life at its various stages and theorize her way of living life in her own way. She keeps on comparing her attitude towards life to that of her mother. At times, she feels her voice taken over by her mother's voice.

You expect a lot from me, don't you?' On the brink of disaster, she pulled herself up, and went on, 'you expect such a lot! You expect me to live like a poor white in this pokey little place of yours. You expect me to cook myself everyday because you won't put in ceilings...' she was speaking in a new voice of a voice she had never used before in her life. It was taken directly from her mother, when she had had those scenes over money with her father' (GIS 79).

There is one conception of the mother which is universal whereas the other notion is more personal and psychological. Lessing and her protagonists present their mothers colored with their subjectivity and in the way as they see her and not as an existence of her own who is torn between her circumstances and her psyche mainly because they do not want the repetition of that. In Under My Skin, though the mother is shown in relation to the father and also in relation to the brother however, the main contention behind doing so is to deduce that the father, Alfred is as unhappy with the wife as Lessing is with the mother. Similarly, her mother's outlook towards the brother Harry is highlighted in Under My Skin because Lessing wants to maintain a comparatively distinctive depiction of mother's discriminatory attitude towards the male child and the female one, denoting her as a symbolic patriarch who falters to be the archetype of the perfect Jungian archetypical mother who is promising enough for the daughter's persona to emulate.

\section{Cyclical Bondage Between Mother-Daughter}

The strength of the bondage between a daughter and mother is as cyclical and repetitive in Under My Skin. It is cyclical in the sense that the daughter becomes or has to become a mother at a particular time in her life. This is a reality that she cannot evade. In the same context, the relationship also repeats itself. According to 
Virginia Woolf, a woman in different stages of her life as a daughter, sister, wife and mother has to undergo somewhat similar circumstances with slight differences (par 2). The story of a woman is wholesomely same with slight variations. When Lessing puts her protagonist in identical socio economic and socio political milieu as that of her mother or her own life for that matter, the heroines like Mary Turner in The Grass is Singing tend to repeat the life of the mother that they are based on (Rich 1)."Matrophobia is a legacy which runs in the family..." (Georgescu 3). It would not be wrong to call it hereditary and the mother transfers her deprived sense of love to the daughter and the daughter, since has never felt the pure essence of motherhood and motherly love cannot share it with her generation and so on.The life of love never experienced by Lessing's mother is a sensitive issue for Lessing too. Chodorow calls the process of mothering as dependent upon number of factors including the past personal and brought up history of the mother herself and her bondage with her natal family (Georgescu 3). When the mother already comes from a past history of being weakly mothered, she infuses the same into her own daughter who is perhaps is sensitive enough to feel it and makes a futile attempt to cure it her own way.

Adrienne Rich propounds that daughter's fear of becoming like the mother is due to mother's falling back to the second class status, turning herself into a victim and not exercising her power (Rich 1). The mother allows inevitable circumstances to prey upon her and disturb her psychologically and emotionally. Emily, Lessing's mother never gets rid of the memory of her fiancé who is usurped in war. Her present life with Lessing's father is unattractive for her. As a daughter, Lessing witnesses the manner in which her father's sexuality is suppressed by her mother's cold behavior. This also leaves a mark on her, especially since her father tells her about it and she has nothing else to think other than wishing that her father should have never shared all this with her though she "was flattered I was his confidante" (UMS 186). At this moment, Lessing feels sorry for her regarding her past and present. According to Lessing this is a problem many marriages suffer from; after getting children, women become so absorbed and obsessed with them that they forget their husbands: "They may very well love their husbands, (UMS 187). Rich puts it this way that these daughters view their mothers as having taught a sense of compromise accompanied with self-hatred. The mothers do try to struggle and win themselves away from it but are unable to do so (Rich 1).

Woolf opines that it is not only the mother with whom the daughter links while remembering or referring her life in connection back but she, saying it more aptly, goes back to the entire generation of her grandmothers and so on and so forth (Abel 
617). In a scenario where mothers have had ambivalent relations with their mothers, the cycle repeats and goes on and on. In other words, matrophobia works in a chain. There seems to be an endless chain of women tied ambivalently to their mothers, who replicate this relation with their daughters(Flax n.pag ). Each daughter is the replica of her mother or her grandmother for that matter. Lessing presents her mother as a daughter who is unloved when she is a daughter. Regarding her own mother Emily, she says ironically, "She had not known love as a child, and was making sure we would not be similarly deprived" (UMS 25). Her mother's monologues in which she states she did not use to breast feed Lessing and make her starve reveal the disturbed psychological state of an unloved daughter who during the course of years becomes a loveless mother to her own daughter. For Object Relation theorists neither the mother nor the daughter can get away with the bond that they share primarily because of the "anatomical sameness" that they have(Daniels n. pag). The mother thus is unable to move past the deprivation offered by the bond and this is why perhaps, Lessing becomes another Emily for her children and this is precisely why the fictive mother Mary is childless. The only time Mary Turner feels an urge to have a baby is when she realizes that life at the bush would eventually crush and shatter her completely and she requires dividing her attention when she has nothing to do (GIS 134). Her maternal instinct also becomes alive however this happens only occasionally as initially she completely rejects the reality of motherhood and growing up children of and for Dick-her husband.

Jamacia Kincaid's one of the fictive pieces The Autobiography of My Mother starts with following symbolic words, "My Mother died the moment I was born..." (Kincaid1). The absence of a mother in daughter's life is one of her most sensitive issues. Writers like Kincaid, Plath or Lessing are so deeply affected by the physical, emotional or natural absence of their mothers in their lives that they pick up the material of their life and write it out as autobiographies. In Emily's case, the immense sense of being abandoned by the mother is reinforced and she makes sure that she deprives her daughter the way she was herself shunned away. It is questionable as to why she does this or whether she does this consciously or unintentionally. In addition, the pattern of repetition is quite prominent here. Later in her life when Lessing creates distances with her own children, this is how she justifies it by saying that the reason she left her children was to "break some ancient chain of repetition" (UMS 262), which was "this secret doom that was inside me - and which had brought my parents to their pitiful condition" (UMS 263). In another interview when talking about abandoning her children of her first marriage she replies in these words, "While it was a terrible thing to do, it was right 
to do" (Allardice par 10). This shows that Lessing as a mother never nurtures a sense of grief or regret on been distanced from her children. She feels that staying close and being indifferent to the child affects the child more negatively than maintaining separation. Mary hates to remember her mother while Martha vows 'never to be like her mother'. In fictive narratives of Lessing, particularly The Grass is Singing, flashbacks of mother and mother's life symbolize the struggle in daughter's own life at the very moment. It is in crisis times that the daughter is reminded back of her mother's life and the moments when the daughter fails or falters as a wife or a mother, she thinks of her mother as a failure. She feels that her fate is repeating for her the same situation which was experienced by the mother particularly the struggle in marital life.

\section{The Patriarchal Mothering}

Feminists have argued that motherhood has the capability to oppress the one being mothered (Hallstein 8). In the same context however contrary to it, if motherhood is expressed wholeheartedly without any reservations then it can be a source of growth, rapid and healthy emotional progress of the child. Motherhood, so "is a complex site of women's oppression and a potential location for women's creativity and joy" (Hallstein 8 ) which depicts that mothering works in two entirely opposite ways. Rich opines in her book Of Woman Born that patriarchal or oppressive motherhood leads to extremely tragic consequences particularly when it comes to the context of mother daughter relationship (Rich 10). The mother exercises her authority over the daughter in all possible ways becoming the microcosm of patriarchy. Mary Turner expresses through flashbacks of her past how her mother prohibited her from doing certain things primarily because she was British English and this where Lessing becomes post colonial thematically. The mother never allows her to mix with the Rhodesian children hence Mary would "linger there for hours, staring at the piles of sticky colored sweets...looking covertly at the little Greek girl whom she was not allowed to play with, because her mother said her parents were dagos" (GIS 1950). Mary's mother inculcates and gifts her daughter the conception of racism simultaneously making her daughter attuned to stay away from the colonized, create psychological fences and maintain her Whitish identity. The later part of the novel, The Grass Is Singing is based of Mary being unable to stand the Black slaves near or around her (1950). She never gets rid of the superiority complex of her race which was germinated in her in the formative and developmental years of her life. 
The psychological dynamics of forcing 'will' upon the daughter affects the daughter in two fold way. At one level, the daughter totally dependents upon the mother with no decision power of her own and at another she turns herself into a rebel against the forced wills of the mother patriarch. In the former, as an adult when the daughter has to part from her mother, she considers that she is being "abandoned" by the mother and she seeks for emotional nurturing all her life to which this parting seems mother's act of shunning away the daughter and resultantly, daughter's psyche gets harmfully hurt due to mother's role as a patriarch. In the latter, the daughter strongly feels an urge of taking her own road to life. In her real life that comes to us through Under My Skin, Lessing has to create separation between herself and her mother to exercise her will on her life. She allows her children to stay separated from her so that she does not force herself on them. If in the first scenario, abandonment on part of the mother takes place, in the second, it is betrayal on past of the daughter that has to be committed for surviving the sense of self and maintaining independence. "A daughter has to betray her mother if she has to exert her own authority" (Flax n. pag). Lessing treats the second consequence of forced will upon the daughter by making her heroines 'runners away' from the oppressive mother figure, society and circumstances.

Lessing as an adolescent had to wage and fight innumerable battles between herself and her mother. Shilpa argues that if during childhood the daughter looks at her mother as a role model then during adolescence she sees her competitively (2). The struggle is initiated on trivial issues as to what to wear or eat. Doris assumes an independent stance in her decision making and decides for herself what she wants to do. However, her clothes could never please her mother and were always in defiance to what her mother wanted her to wear. "My fourteenth was a make or break year, a sink or swim year, a do or die year, for I was fighting for my life against my mother. That was how I saw it. That was how it was" (UMS 155). Lessing did not view her mother a life saver or a protector as a teenage but as hindrance or obstacle in exercising her own will freely. She also developed an obsession with her body as an adolescent which her mother strongly disapproved of; but the more the mother disapproved, the more the deviant attitude became powerful and the more the daughter became engaged in such rebellion. All this deepened the anger that Doris felt for her mother and made her even more determined to fight back. As a result, the main drive in her life was never to resemble her parents particularly her mother in any way. She repeatedly tells herself that she has the power to be unlike her parents in all possible ways. In the circle of family, "the daughter sees the mother as both powerful and powerless" (Flax n.pag.). She views her as an entity that has considerable control over her 
circumstances. However, the daughter is unable to fathom out the inevitable dominance of father and mother's husband in the family and the daughter finds her mother herself letting power go away from her hands and simultaneously becoming a desperate seeker of the lost power becoming a woman who lets go of her will power and does nothing to make it stay with her and practice it.

This is true to Lessing's own mother in Under My Skin and Mary Turner's mother in The Grass Is Singing. Lessing presents a mother who is both hopeful and hopeless about her life. This intrigues the psyche of the daughter who fails to understand such behavior of the mother. It is unintelligible for Mary as to why her mother always had to act as a martyr and cry sorrowfully on the plight of living below the poverty line. Mary gauges that her mother had full potential of contributing something to the family and there are times when the mother's coquettish attitude towards the customers gives her second thoughts as to viewing her mother as helpless or full of strength. Her mother's married life is narrated by her with the words and phrases like 'resentment', 'complaining', 'parading her sorrow', and 'father and mother fought' (GIS 1950). The memory of her mother's life stays fresh for Mary and she is reminded of it strongly when she herself reaches the age and circumstances as that of her mother. Her life with Dick Turner is similar to that of Lessing's own mother with her husband. Lack of understanding, love, devotion or care is the common factor that unites the two pairs. What leads Lessing to re create a pair that resembles her own parents clarifies how deeply the relationship of her parents affected and touched her psychologically. Just like Lessing's mother who has the talent or creativity to take the family out of financial miseries, Mary also realizes that she can manage a better, efficient and sound business individually and show Dick Turner the places where he is wrong. However, Mary is unable to do so just like the way Lessing's mother is unable to do so. There are instances when she identifies with her mother, but mostly tries to distance herself from her parents as she is terrified by how weak and pitiable they turned out to be: "It was not my parents' strength that threatened me, it was their weakness" Lessing exclaims in her autobiography (UMS 189). More than living the kind of life that her mother had, Lessing fears to repeat the helplessly domestic life of her mother. A life stuck with domesticity is nightmarish for her (Scott par 2).

The dwelling upon on mother figure in fiction does suggest that it is only by learning to love her mother again, by recuperating a love disrupted by the patriarchal colonial order, can a woman claim her own identity. In her second volume Walking in the Shade which was written in 1997 after her mother died, 
Lessing turns out to overwhelmed with pain and grief, she contemplates and relates if she could have behaved and acted differently with her mother. She realizes that had her mother been was still alive, she would have been the same but now that she has become old herself, she imagines that she could understand and communicate better with her mother. She feels her mother to be fairly comprehendible to her now at this moment of her life when she is almost as wrinkled as her mother was. Lessing words have an impulsive charge when she wishes to put her arms around her mother but interestingly it is not Emily as Lessing's mother that she empathizes with but the little Emily who lost her mother as a baby girl, who had to fend all her life in a wilderness of being a child who never has the feel of maternal love and was left to be brought up by servants, unloving stepmother and a cold dutiful father. Lessing does not remember and recall her mother as a mother but as a baby girl and teenage daughter whose life was full of deprivations. Jungian analysis of such a situation is the one of fathoming out "infantile neurosis" of not the child who is the receiver but in the mother who must have had traumatic experiences in her life as a child (Jung 139-140). Hence, it is clear that a daughter's identity does not thrive in isolation or negation. It establishes itself in acceptance. Lessing tries to establish her sense of self by writing her Self out and giving prominence to the mother figure. She formulates a creative narrative in the shape of her autobiography and fiction in order to conceptualize her sense of self.

Lessing advocates the freedom of daughter but also advocates connectedness along with autonomy. Why is it so that the daughter dwells upon the life and memory of her mother to such a large extent and why is it so that the daughter has such a concrete idea of the circumstances of her mother's life that when the cycle of repetition occurs, she is able to relate to it at once. The belief is merely what Lessing propounds an inevitable linkage between the daughter and the mother. In spite of matrophobic projection of mother daughter relationship, Lessing does not express denunciation, rejection or shunning away of the presence and memory of mother in daughter's life both at fictive and autobiographical levels. She, contrary to it, seeks to get an answer to all those questions that create complexity in the mother daughter dyad. She aims at psychotherapy of her matrophobia and there are clear and vivid clues that Lessing as an author, leaves for the reader certain clues where it is obvious that she is sitting back, giving herself a moment to contemplate and ponder over the intricate nature of this relation. Relating truth of her life through an autobiography there are degrees of confessions, evasions and acceptance on her part when she analyzes her place and role on the pair of herself and her mother in a relation that is timeless and naturally connected till she breathes. 
The psychodynamics of mother daughter relationship with the various degrees of oppression on part of the mother, deprivation in terms of the exchange of love and dispossession on part of the daughter, in the fiction and autobiography of Doris Lessing reveals the prominently complicated debate or tussle between two women, one of which is born of the other and the crucial role that identity of both plays in this regard. The daughter's development from babyhood to becoming a mother is colored by her experiences of maternal love. Through various stages of growth during her life Lessing portrays how her relation with the mother kept on developing and more importantly changing. Lessing's relation with her own mother and that of her protagonists bring to light the aspect of Matrophobia which makes the daughter conscious of preventing her identity from being fissured or repeating mother's life in any way. The mother becomes a defining source in the life of the daughter and significantly affects her concept of womanhood, motherhood, family and home. Here, the father also becomes important who acts as a comparative agent while measuring love or lack of love from the mother. The debate of the tussle or conflict between daughter and mother and Lessing's treatment of this issue is ongoing however, the psychotherapeutic tinge in it is quite prominent. Feminists including Nancy Chodorow and Adrience Rich and psychoanalytic theories of Object Relation and Development provide varied dimensions of understanding it but Lessing's treatment of the phenomenon is deep and dense. She invites for a more thorough penetrating into the issue where the act of mothering becomes increasingly dynamic, volatile and critical as far as it has been projected in her works.

\section{References and notes:}

Abel, Elizabeth.Virginia Woolf and the Fictions of Psychoanalysis. 1890. London: UP of Chicago.

Allardice, Lisa."LisaAllardice on Doris Lessing: She Helped Change the WayWomanarePerceived and Perceive Themselves." The Guardian.

Boyd, Carol. J. "Mother and Daughters: A Discussion of Theory and Research." Journal ofMarriage and Family.51. 2: 1989. 291-301.

Chodorow, Nancy.The Reproduction of Mothering: Psychoanalysis and The Sociology of Gender. 1978 USA: U of California Press.

---,"Family Structure and Feminine Personality."Women, Culture and Society.Ed.MichelleZimbalist Rosaldo and Louise Lamphere.1974. Stanford: U of Stanford Press.

Flax, Jane."Mother-Daughter Relationships: Psychodynamics, Politics, and Philosophy."TheScholar \& Feminist XXX: Past Controversies, Present Challenges, FutureFeminists. 1985 3.3.

Gerorgescu, Anca."Reconstructing Mother- Daughter Subjectivities through Writing in Doris Lessing's Under My Skin.”1998 .Valahia: U of Targoviste P. Print.Greene, Gayle. The Poetics of Change.USA. 1994. U of Michigan.Print. 
Hallstein, Lynn O'Brien. White Feminists and Contemporary Maternity: PurgingMatrophobia.2010. New York: Palgrave Macmillan, Print.

Hirsch, Marianne and Evelyn Fox Keller."Introduction: January 04, 1990." Conflicts inFeminism.Eds. Marianne Hirsch and Evelyn Fox Keller. 1990. New York:Routledge. 12. Print.

Kincaid, Jamaica.The Autobiography of My Mother. New York: Plume Books. 1996 Print.Rich, Adrienne. Of Woman Born: Motherhood as Experience and Institution. 2nd ed.1996.New York: W.W. Norton.Print.

Schlueter, Paul. "Self Analytic Woman: The Golden Notebook." "Doris Lessing". ModernCritical Views.Ed. Harold Bloom. New York: Chelsea House Publishers. 1976. 46-47.Print.

Scott, Lynda. "Writing the Self- Selected Works of Doris Lessing." 2013. Deep South. Shilpa, P. "Mother Daughter Relationship: Daughter's Experience." 2010. Diss. Bangalore U of Christ.

Woolf, Virginia. "A Room of One's Own”. Abrams, M.H. The Norton Anthology of English Literature. New York: Norton \& Company, 2000. Print.

\title{
Summary
}

\section{Psychodynamics of Mother Daughter Relationship: Degrees of Deprivation, Oppression and Dispossession in Doris Lessing's Fiction}

\author{
Rabia Ashraf \\ COMSATS Lahore, Pakistan
}

Contextualized within psychoanalytic feminist critique, this study aims at fathoming out various dynamics operating at psychoanalytic level within the mother daughter relationship that affect daughter's level of intimacy or repulsion towards the mother in the texts of Doris Lessing, in particular The Grass is singing (1950) and Under My Skin (1994). While focusing on these works and approaching them through a feminist critical perspective of the phenomenon of motherhood, mothering and matrophobia, I have consider a re-examination of Lessing's attempt to provide an inevitably fresh stance of mother daughter dyad's tussle. The research contends that by breaking idealized boundaries and positioning mother as an independent entity- the phenomenon of matrophobia -daughter's hatred towards the mother in early phases of her life is explored. Throughout the paper, it has been established that Lessing consciously relates the mother moving towards and away from the being of daughter at both fictional and biographical planes.

Key Words: Psychoanalysis, Feminism, Matrophobia, Motherhood, Mothering 